\title{
Arabic vocabulary mastery in early childhood through singing
}

\author{
Meutia Rahmah ${ }^{1}$, Ade Tursina ${ }^{2}$, Nuraisyah ${ }^{3}$ \\ 1,2,3 Department of Islamic Early Childhood Education, Institut Agama Islam Negeri Langsa, Indonesia \\ ${ }^{*}$ Corresponding author
}

$\begin{array}{ccc}\text { First received: } & \text { Revised: } & \text { Final Accepted: } \\ 13 \text { August 2021 } & 15 \text { November 2021 } & \text { 30 December 2021 }\end{array}$

\begin{abstract}
As a foreign language, children aged 5-6 years in Langsa are still lacking in mastering Arabic vocabulary. This study aims to describe how the singing method enriches children's Arabic vocabulary. The research applied Classroom Action Research (CAR) design with the Kemmis and Mc. Taggart in two cycles. Each cycle consists of four stages; planning, implementing actions, observing, and reflecting. The research subjects were 6 children in Gampong Geudubang Aceh, Langsa. The result shows that Arabic vocabulary mastery of early childhood through the singing method has increased in each cycle. The first cycle obtained $44.66 \%$ on average and the second cycle increased to $80.3 \%$ in its average. It can be concluded that the singing method can increase the mastery of Arabic vocabulary for early childhood.
\end{abstract}

Keywords: Arabic Vocabulary, Singing Method, Early Childhood

${ }^{2}$ Corresponding Author:

Department of Islamic Early Childhood Education,

Institut Agama Islam Negeri Langsa, Indonesia

Email: adetursina@iainlangsa.ac.id 


\section{INTRODUCTION}

Early Childhood Education (ECE) is a coaching effort aimed at children from birth to the age of six which is carried out through the provision of educational stimulation to help physical and spiritual growth and development so that children have the readiness to enter further education. Based on the Regulation of the Minister of National Education No. 58 of 2009 concerning Standards for Early Childhood Education, it is stated that one of the ECE standards is the standard of developmental achievement level, which contains the rules for the growth and development of early childhood from birth to the age of six. The child's development achieved is an integration of understanding aspects, namely religious and moral values, physical motoric, cognitive, social-emotional, language, and art. This is important for children because developing these abilities will make it easier for children to continue to the next stage of education (Depdiknas, 2009).

One of the abilities that must be developed by children is the aspect of language development because language skills are very important things that must be possessed by humans, especially children. With language, a person can communicate well with others. According to Vygotsky, language is a tool for expressing ideas and asking questions, and language also produces concepts and categories of thinking. In addition, language is also the main communication tool for a child to express his various desires and needs (Susanto, 2012).

In communicating, language is an important tool for everyone. Through language, a person or child will be able to develop social skills with other people (Asef, 2018). Language is a symbol, sound, or symbol. In the sense of the word language is an orderly system of sound symbols used to express the feelings and thoughts of the language. Language can be obtained from an early age, language acquisition is obtained from the first language (mother tongue) and the second language, namely the language in the environment or foreign language, one of which is Arabic (Mahriza, Meutia, Nina, 2019).

In Indonesia, apart from using Indonesian which is the national language, we also know other languages, one of which is Arabic, which is still well-known in Indonesia. Arabic is a foreign language because it is not the language of everyday life. This can be seen in Islamic schools generally ranging from kindergarten to college(Ibrahim, 2011) . Arabic is positioned as a foreign language, including its position in the curriculum. Another thing that can be used as an indicator of the foreignness of schools is that Arabic is not used as the language of instruction, but as a subject matter (Acep Hermawan, 2018).

In the process of learning Arabic, there is a vocabulary that is an important aspect of all aspects of the language that must be mastered. A vocabulary is a small unit that determines the strength of language. Vocabulary is an added value for Indonesians to learn Arabic easily, because the more Arabic vocabulary used in the Indonesian National 
language, the easier it is for Indonesians to build vocabulary, give understanding, and put it in memory. With good mastery of Arabic vocabulary, early childhood will have additional knowledge that is useful when entering a higher basic education level, namely Elementary School or Islamic Elementary School, and most importantly, students are equipped with the ability to understand simple words and pronounce language vocabulary correctly(Nasional et al., 2016).

This makes researchers interested in conducting this research. Based on the results of observations in the field, from the results of observations made, in Gampong Geudubang Aceh in the 2020/2021 academic year, the mastery of Arabic vocabulary in early childhood has not been widely introduced, because Arabic is not a daily language (a language that is often used) so that children rarely hear it. Regarding Arabic for early childhood in Gampong Geudubang Aceh, it has been implemented with the existence of TPQ or Koranic places, and not all Koran places teach Arabic vocabulary. However, in mastering Arabic vocabulary, it is only taught to elementary and junior high school-age children, while children aged 5-6 years are not applied in vocabulary mastery but are only introduced to hijaiyah letters (Iqra). Thus, researchers are motivated to research Arabic vocabulary mastery in early childhood as one of the ways to improve early childhood language skills, especially in the introduction of Arabic vocabulary. Considering that early childhood is the age where children play, efforts to create a learning atmosphere can be realized by the singing method which contains poems that are following the material to be taught which aims to determine the increase in mastery of Arabic vocabulary through teaching and learning (Mahriza et al., 2021).

There are several relevant previous studies for us to review. First research from (Fauziddin \& Tambusai, 2020) regarding recognizing Arabic vocabulary through Hijaiyah letter card games equipped with Vocabulary. The results obtained through Hijaiyah letter card games equipped with vocabulary can attract children's attention so that learning activities are more effective so that it affects the improvement the ability to recognize Arabic vocabulary, especially Arabic vocabulary on the card. It can be concluded that the use of Hijaiyah letter card games equipped with Arabic vocabulary can improve the ability to recognize Arabic in early childhood. The two researchers also reviewed the research journal belonging to (Munawaroh, 2017) in their research to improve Arabic vocabulary mastery in early childhood through singing at RA Masitoh Salatiga in the 2016/2017 academic year, showing the results of research that through the singing method Arabic vocabulary learning can easily absorbed by children. The application of the singing method influences increasing mastery of Arabic vocabulary in early childhood at RA Masitoh Salatiga in the 2016/2017 academic year, with the result that $53 \%$ of students complete learning in cycle I, then the second cycle as much as $94 \%$.

The three studies from (Azzahra, 2017) discussed improving Arabic Vocabulary Recognition through the use of picture media in group B children at RA Al-Jannah Jakarta 
which concluded that the percentage of children's Arabic vocabulary recognition abilities from pre-study to the end of cycle II increased by $56 \%$. It can be seen that the children can carry out activities and create a class into conducive. The ability to recognize Arabic vocabulary has also increased because children can recognize the vocabulary of numbers 1 to 10 and vocabulary of 10 kinds of pets, besides that children can interpret numbers in Arabic, sorting numbers from the smallest to the largest with Arabic numbers, children can understand and understand what is instructed by the teacher with picture cards, children can write and thicken Arabic letters and children can sing Arabic vocabulary songs.

The innovation in this article is to increase Arabic vocabulary in early childhood; researchers use a singing method that is adapted to the theme of learning for early childhood where other researchers have not used it. The researcher chose the singing method because after conducting pre-observation in the village of Gampong Geudubang Aceh, it turned out that the introduction of Arabic vocabulary had never been done to early childhood, so far they were only introduced to the letters hijaiyah (Iqra). Given that early childhood is the age where children play, the effort to create an atmosphere of introducing Arabic vocabulary designed by researchers can be realized by the singing method which contains poems that are by the theme of learning to be taught which aims to determine the increase in mastery of Arabic vocabulary through the singing method in Gampong Geudubang Aceh.

\section{METHOD}

The location of this research was carried out in Geudubang Aceh Village, Langsa Baro District, Langsa City in the 2020/2021 academic year. The research subjects are children aged 5-6 years with a total of 6 children, namely 4 boys and 2 girls. The research method uses classroom action research which consists of 2 cycles, namely in the first cycle starting from 28 September 2020 to 02 October 2020 and the second cycle starting from 05 October to 09 October, where each cycle consists of 5 times. The research method used is Classroom Action Research (CAR). Classroom action research is an observation of learning in the form of actions that are intended to be carried out and carried out in class in unison (Arikunto, 2015)

The research, it is necessary to have a research design or design to make it easier for researchers when carrying out research (Iskandar, 2015). The design of this study used the Kemmis and Taggart classroom action research model, which uses a spiral system where each cycle consists of four stages, namely planning, implementation, and observation and reflection, (Arikunto \& Supardi, 2017).

The collecting data in this study uses interview, observation, and documentation techniques that have data collection instruments as a tool used by researchers in data collection activities and so that these activities become systematic, such as a grid of observation sheets. When interpreting the results of the analysis carried out during the activation process, the researcher used percentage analysis to obtain an overview of efforts to 
master Arabic vocabulary in early childhood through the singing method. The score to determine the percentage of each observer's actions on the researcher's activities is by the formula:

As for determining the percentage score of each observer's actions on research activities, namely by using the formula (Purwanto, 2006):

$\mathrm{NP}=\frac{R}{S M} \times 100 \%$

NP : percent value sought or expected

$\mathrm{R} \quad$ : the number of students who completed

SM : total number of students

$100 \%$ : fixed number

According to Syahwani and Syahbasril to analyze the categories of teacher abilities in designing and implementing learning can be seen in the following table (Sumarni, 2015):

Table 1. Benchmarks of Teacher's Ability in Designing and Implementing Learning

\begin{tabular}{|l|l|c|}
\hline No & Score & Category \\
\hline 1 & $1.00-1.99$ & Less \\
\hline 2 & $2.00-2.99$ & Enough \\
\hline 3 & $3.00-3.49$ & Good \\
\hline 4 & $3.5-4.00$ & Very Good \\
\hline
\end{tabular}

The criteria for the success rate of the learning process in the learning process are determined as follows (Khotijah, 2018):

Table 2. Criteria for Mastery of Arabic Vocabulary Mastery in Children

\begin{tabular}{|c|c|}
\hline Criteria & Percentage (\%) \\
\hline Very well developed & $75 \%-100 \%$ \\
\hline Develop as expected & $50 \%-74,99 \%$ \\
\hline Start to develop & $25 \%-49,99 \%$ \\
\hline Undeveloped & $0 \%-24,99 \%$ \\
\hline
\end{tabular}

And this research is considered successful if the results achieved by the child have reached $80 \%$ in mastering Arabic vocabulary in early childhood through the singing method.

The procedure in this study uses stages since there are assessed and planned actions in the cycle (Nur Hamim and Husniyatus Salamah, 2009) so that the design in this study was carried out in 2 cycles. The following are the stages of classroom action research conducted by researchers: 


\section{CYCLE I}

\section{a. Planning}

At the planning stage, the researcher designs the actions to be implemented. Make a Daily Learning Planning Plan (RPPH) for one cycle. The RPPH was prepared by the researcher with consideration. RPPH is useful as a guide for researchers in carrying out classroom learning. Develop research and assessment instruments by making observation sheets that will be used in observing children when learning Arabic vocabulary through the singing method. Prepare learning media to be used, namely letter cards and flip cards.

\section{b. Implementation}

The implementation of the actions in cycle I was carried out with 5 meetings starting from September 28, 2020 - to October 2, 2020. The researcher functioned as implementers of learning and as observers. At the first meeting, the researcher started the lesson by greeting, reading the study prayer, and doing self-introductions. Then the researcher introduced the hijaiyah letters through the media of letter cards and the children read the hijaiyah letters. This is done to increase the ability of children to easily pronounce Arabic vocabulary given based on vowels in Arabic vocabulary.

\section{c. Observation}

Along with the action stage, the researcher made observations and the observation stage. At this stage, direct observations were made by observing children in learning activities. At the observation stage, the researcher acts as a teacher and also as an observer. The indicators observed were the child was able to repeat words in Arabic vocabulary, understood vocabulary, was able to answer simple questions, was able to mention pictures in Arabic, and could sing vocabulary songs in Arabic.

Observations in the Cycle I learning process were carried out well although sometimes there were a few obstacles, namely, there were children who had difficulty in pronouncing vocabulary and there were children who still liked to annoy other friends. However, overall the children were very enthusiastic and very happy. This is because learning in Arabic vocabulary mastery uses the singing method which is a method suitable for early childhood that makes it easier for children to remember.

The results of the children's ability to master Arabic vocabulary in Cycle I showed that there was an improvement during the action. This increase occurred because children were easier to understand and remember vocabulary in Arabic through the singing method. Based on observations, some children can pronounce vocabulary and sing vocabulary in Arabic. In the indicators contained in the observation sheet, several children learn with the help of the teacher and not with the help of the teacher either smoothly or not smoothly. 


\section{d. Reflection}

The implementation of reflection is carried out at the end of the first cycle by the researcher which aims to determine the level of success and learning that has been carried out. In this case, the researcher evaluates several actions that have been applied to be improved in the next action. Based on the results of observations, several things become obstacles, including:

1. During the learning process, some children are still difficult to pronounce (pronounce) Arabic vocabulary

2. During the learning process there are still children who play by themselves during the learning process.

Thus, the researcher plans to re-plan the learning action in mastering Arabic vocabulary using the singing method for Cycle II because the expected success criteria have not been achieved through the results of reflection. Researchers will optimize the increase in mastery of Arabic vocabulary using the singing method with predetermined success indicators so that later using this method in Cycle II can increase mastery of Arabic vocabulary after reflection.

\section{CYCLE II}

\section{a. Planning}

The implementation of the actions in cycle II was carried out for 5 meetings, namely on October 05 - October 09, 2020. The planning carried out in Cycle II was almost the same as the planning in Cycle I. Planning in this cycle began with planning and determining the implementation plan of the lesson. (RPPH), plan the lessons contained in the RPP and determine success indicators. The next stage is to prepare the facilities and infrastructure used in learning activities and to prepare cameras to document activities during teaching and learning.

\section{b. Implementation}

The implementation of the actions in Cycle II is the same as in Cycle I with 5 meetings. The reasearch started on October 05, 2020 into October 09, 2020. On the first day of Cycle II, Monday was October 05, 2020. In the early learning activities, the researchers put the different positions of the children. For children who have difficulty understanding vocabulary, the researcher positions his seat in front of the researcher so that it is easier for researchers to monitor children's development. Then the researcher started the activity by greeting, asking how things were, asking for the day, read prayers before studying, and telling the theme to be studied. 
The researcher invites the children to discuss the parts of the body through the media that has been pasted on the wall. The researcher ordered the children to pay attention to the media. Then the researcher showed the body parts of the puppets and showed the parts of the limbs. Researchers practice how to use the media by attaching body parts. Then, the researcher allowed the children to take turns doing these activities with the researcher asking what part this is, come on, who knows what name the mother is pointing at, raise her hand, whose child is the first to answer. Then the researcher pronounces the vocabulary from the body parts one by one by showing the shape of the media. For example, "sya'run = hair" to "rijlun = legs". After that, the researcher gave a song related to the theme. The researcher tried to sing the song first and then asked the children to follow it while doing the movements according to the song. At the end of the activity, the researcher asked the child's feelings today after attending the lesson, told the activities to be carried out tomorrow, read the Prophet's prayer, and closed.

On the next day was Tuesday, October 6, 2020. Researchers took action the next day. The researcher said greetings, asked how the children were doing, read a prayer before studying, and announced the theme to be studied. Then the researchers discussed the body parts and their Arabic vocabulary again. After that, the researcher asked the children to stand up to repeat the Arabic vocabulary about parts of the body by showing the members on their bodies, then the researcher and the children sang Arabic vocabulary songs about body parts together. After finishing singing, the researcher gave a task in the form of thickening the lines in Arabic vocabulary related to the theme and after completing the task the researcher repeated the song given.

At the end of the learning activity, the researcher asked the children's feelings after participating in today's activity, the researcher also informed the activities that would be carried out tomorrow, the researcher and the children read the Prophet's prayer and the researcher said greetings as the closing of the lesson.

The third meeting in Cycle II was Wednesday, September 7, 2020. Before the researchers carried out learning activities, the researchers ordered the children to move their bodies by doing movements using rhythm. After that, the researcher ordered the children to sit down and start learning by saying greetings and reading a prayer to learn. Then the researchers discussed the functions of the parts of the body through the media used. After that, the researcher and the children sang Arabic vocabulary songs about body parts together. After finishing singing, the researcher asked about the next activity. To enter the next activity, which is playing treasure trove related to Arabic vocabulary on the limbs; it is carried out with the researcher's instructions that the child is to look for a roll of paper containing pictures and Arabic vocabulary in a hiding place. Then ask the child to name the picture that he got along with its meaning and give the child a break for 10 minutes. At the end of the activity, the researcher asked the children to repeat the song about Arabic 
vocabulary together, and then the researcher asked the child's feelings after participating in the activity, reading the Prophet's sholawat and saying greetings.

On the next day was Tuesday, October 6, 2020. Researchers took action the next day. The researcher said greetings, asked how the children were doing, read a prayer before studying, and announced the theme to be studied. Then the researchers discussed the body parts and their Arabic vocabulary again. After that, the researcher asked the children to stand up to repeat the Arabic vocabulary about parts of the body by showing the members on their bodies, then the researcher and the children sang Arabic vocabulary songs about body parts together. After finishing singing, the researcher gave a task in the form of thickening the lines in Arabic vocabulary related to the theme and after completing the task the researcher repeated the song given.

At the end of the learning activity, the researcher asked the children's feelings after participating in today's activity, the researcher also informed the activities that would be carried out tomorrow, the researcher and the children read the Prophet's prayer and the researcher said greetings as the closing of the lesson.

At the third meeting in Cycle II was Wednesday, September 7, 2020. Before the researchers carried out learning activities, the researchers ordered the children to move their bodies by doing movements using rhythm. After that, the researcher ordered the children to sit down and start learning by saying greetings and reading a prayer to learn. Then the researchers discussed the functions of the parts of the body through the media used. After that, the researcher and the children sang Arabic vocabulary songs about body parts together. After finishing singing, the researcher asked about the next activity. To enter the next activity, which is playing treasure trove related to Arabic vocabulary on the limbs, it is carried out with the researcher's instructions that the child is to look for a roll of paper containing pictures and Arabic vocabulary in a hiding place. Then ask the child to name the picture that he got along with its meaning and give the child a break for 10 minutes. At the end of the activity, the researcher asked the children to repeat the song about Arabic vocabulary together, and then the researcher asked the child's feelings after participating in the activity, reading the Prophet's sholawat, and saying greetings.

The fourth meeting was Thursday, October 08, 2020. The researcher opened the lesson by greeting, asking how things were, reading the study prayer, and clapping. Then the researchers discussed some of the functions of the limbs and repeated the pronunciation of Arabic vocabulary on the limbs together. Then, children carry out activities in the form of collating Arabic vocabulary that has been exemplified by previous researchers. After that, the researcher asked the children to sing Arabic vocabulary songs about body parts together. To end the lesson, the researcher asked what activities had been done today, informed the activities to be carried out tomorrow, read the Prophet's prayers, and concluded. 
The fifth (last) meeting in Cycle II was Friday, October 09, 2020. At the beginning of the lesson, the researcher conducted the opening SOP and read the prayer, and the researcher informed about today's activity, which was to repeat the lesson that had been done the previous day. On this day the researchers reviewed the development of children in mastering Arabic vocabulary with researchers conducting questions and answers to children about parts of the body in Arabic. Then the researcher ordered the children to come forward, in turn, to sing Arabic vocabulary songs and give appreciation in the form of gifts. At the end of the activity, the researcher closed the lesson by reading the Prophet's prayers and greetings.

In each meeting, the researchers conducted an assessment of the child's development at the time of learning. This assessment is carried out through an observation sheet which contains several indicators regarding the mastery of Arabic vocabulary in early childhood including the child being able to repeat words in Arabic vocabulary, understanding vocabulary, being able to answer simple questions, being able to mention pictures in Arabic and singing songs about subtitles given theme.

\section{c. Observation (Observation)}

Observations were carried out during the learning process by using direct observation when the child was learning Arabic vocabulary as was done in cycle I. The indicators observed were the child was able to repeat words in Arabic, understood vocabulary, was able to answer simple questions, the child was able to name pictures. in Arabic, as well as singing Arabic vocabulary songs. Based on observations on each of these indicators, it can be seen that most of the children already have the ability to master the Arabic language indicator, so that overall the children experience an increase in the mastery of Arabic vocabulary in Cycle II.

\section{d. Reflection}

Based on the implementation of the actions in Cycle II, it was found that learning activities to improve mastery of Arabic vocabulary through the use of the singing method worked well compared to learning activities in Cycle I. During the learning process in Cycle II, it could be reflected as follows:

1. It was seen that the children became interested in the use of the singing method in Cycle II so that they were more enthusiastic about participating in learning.

2. By improving the arrangement of the sitting position for children who are less fluent in mentioning Arabic vocabulary, they are positioned close to the researcher so that learning is seen to be conducive and has increased for children who are less fluent in mentioning Arabic vocabulary. 
3. With awards in the form of words such as "smart", "good", "clever", "great" makes children feel happy because they get prizes in the form of praise.

The results of the reflection obtained in Cycle II, it can be concluded that the use of the singing method to improve Arabic vocabulary mastery for children aged 5-6 years in Gampong Geudubang Aceh has been successfully implemented and has met the success criteria that have become the objectives of the study, namely children who have achieved an indicator of the ability to improve mastery of Arabic vocabulary on a good criterion of at least $80 \%$ and this is following this success indicator.

\section{FINDINGS}

The results of the research obtained through interviews with children's parents that not all parents teach the Arabic vocabulary that the researcher means. Parents are happy to see their children are familiar with hijaiyah letters, prayers, and surahs.

In addition to interviews to find the expected data, researchers also made observations by conducting classroom action research. The researcher created a research class to be studied which contained 6 children in Geudubang Aceh Village. During the process of activities including planning, implementing, observing, and reflecting on corrective actions in cycle I, they are as follows:

Table 3. Data on Assessment Results of Cycle I Classroom Action Research

\begin{tabular}{|c|c|c|c|c|c|c|c|}
\hline \multirow[t]{2}{*}{ No } & \multirow[t]{2}{*}{ Student Name } & \multicolumn{4}{|c|}{ Value } & \multirow{2}{*}{$\begin{array}{l}\text { Total } \\
\text { Score }\end{array}$} & \multirow{2}{*}{ Ket } \\
\hline & & Score 1 & Score 2 & Score 3 & Score 4 & & \\
\hline 1 & Respondent 1 & 12 & 20 & 12 & 0 & 42 & $\mathrm{MB}$ \\
\hline 2 & Respondent 2 & 16 & 18 & 3 & 0 & 37 & MB \\
\hline 3 & Respondent 3 & 15 & 18 & 3 & 0 & 36 & MB \\
\hline 4 & Respondent 4 & 2 & 34 & 12 & 8 & 56 & $\mathrm{MB}$ \\
\hline 5 & Respondent 5 & 11 & 24 & 6 & 0 & 41 & $\mathrm{MB}$ \\
\hline 6 & Respondent 6 & 2 & 34 & 12 & 8 & 56 & $\mathrm{MB}$ \\
\hline \multicolumn{7}{|c|}{ Total Score } & 268 \\
\hline \multicolumn{7}{|c|}{ Average } & 44,66 \\
\hline \multicolumn{7}{|c|}{ Students Achievement in Minimum Criteria\% } & $44,66 \%$ \\
\hline
\end{tabular}

Based on the data in the table above, in the first cycle, it can be seen that the children's ability in mastering Arabic vocabulary in Cycle I shows that there are 6 (100\%) children in the criteria for starting to develop (MB). From these results, children can begin to master Arabic vocabulary through singing method. This means that the improvement activities in cycle I have not been successful. Based on the results of the reflection on the activities of the first cycle, for that in the implementation of learning in the second cycle of activities, improvements were made to learning with the following results and findings: 
Table 4. Data on the Results of Cycle II Classroom Action Research

\begin{tabular}{|c|c|c|c|c|c|c|c|}
\hline \multirow[t]{2}{*}{ No } & \multirow[t]{2}{*}{ Students Name } & \multicolumn{4}{|c|}{ Value } & \multirow[t]{2}{*}{ Total Scor } & \multirow{2}{*}{ Ket } \\
\hline & & Score 1 & Score 2 & Score 3 & Score 4 & & \\
\hline 1 & Respondent 1 & 0 & 10 & 21 & 52 & 83 & BSB \\
\hline 2 & Respondent 2 & 0 & 16 & 27 & 32 & 75 & BSB \\
\hline 3 & Respondent 3 & 0 & 18 & 33 & 20 & 71 & BSB \\
\hline 4 & Respondent 4 & 0 & 6 & 21 & 60 & 87 & BSB \\
\hline 5 & Respondent 5 & 0 & 10 & 27 & 44 & 81 & BSB \\
\hline 6 & Respondent 6 & 0 & 8 & 21 & 56 & 85 & BSB \\
\hline \multicolumn{7}{|c|}{ Total Value } & 482 \\
\hline \multicolumn{7}{|c|}{ Average } & 80,33 \\
\hline \multicolumn{7}{|c|}{ Students Achieve } & $80,33 \%$ \\
\hline
\end{tabular}

According to data from the table of assessment results in cycle II, the ability of children in mastering Arabic vocabulary in Cycle II shows that there are 5 (83\%) children in the criteria for developing very well and as many as 1 (33\%) in developing criteria as expected. From these results, all of them have increased which indicates that children can understand Arabic vocabulary in the form of pronouncing Arabic vocabulary and children can sing Arabic vocabulary which is expected by researchers. The results of the reflection obtained in Cycle II, it can be concluded that the use of the singing method to improve Arabic vocabulary mastery for children aged 5-6 years in Gampong Geudubang Aceh has been successfully implemented and has met the success criteria that have become the objectives of the study, namely children who have achieved an indicator of the ability to improve mastery of Arabic vocabulary on a good criterion of at least $80 \%$ and this is by this success indicator.

This means that the improvement activities in cycle II have been successful. Thus, through the singing method activities can improve Arabic vocabulary mastery in early childhood in Gampong Geudubang Aceh, Langsa City. Thus, it can be stated that the activity using the singing method was successful so that the improvement of the activity reached cycle II and there was no need to carry out repairs in cycle III.

\section{DISCUSSION}

Early childhood is children who are at a very young age, so early childhood requires serious care from parents and their environment. According to Maimunah Hasan, early childhood is a child who is in the age range from birth to the age of 6 years. At this age, children need to get attention in their growth and development which is carried out through the provision of educational stimuli to help physical and spiritual growth and development, so that children have the readiness to enter further education which is held on formal, nonformal and informal channels. In line with the above opinion, Mansur (2005) stated that early 
childhood is children from birth to entering basic education. Early childhood is a golden age as well as a critical period in the stage of life that will determine the next child's development. This period is the right time to lay the foundations for development as well as physical, language, socio-emotional, self-concept, art, morals, and religious values. One of the abilities that must be developed by children is the aspect of language development because language skills are very important things that must be possessed by humans, especially children.

For this reason, the research carried out has the aim of mastering Arabic vocabulary for early childhood in Gampong Gedubang Aceh, Langsa City through the Singing Method. According to Kamtini, the singing method is a learning method in which it contains a means of expressing thoughts and feelings because singing is important for children's education besides singing is a fun activity that gives satisfaction to children. The singing method is a method that uses a song that contains learning messages, if spoken it will produce a tone from the voice that sings a song (Risaldy, 2014). According to Jamalus who revealed that singing is an art, to express human thoughts and feelings through tones and words (Isnaningsih, 2016).

From the opinion above, it can be concluded that the singing method is a method or learning method that uses songs or rhythmic songs containing learning messages that will be conveyed so that learning is well received. It is because singing is one of the most popular activities for children. The swaying words accompanied by the strains of music can give them their spirit, and it is not uncommon for the teacher to teach or memorize something by sound. With the lyrics in such a way, it can help memory with the way children speak.

So far, the introduction of Arabic vocabulary in early childhood has not been specifically introduced in Gampong Gedubang Aceh, Langsa City, because Arabic is considered not a daily language (a language that is often used) so that children rarely hear it(Shiddiq, 2008). The introduction of Arabic to early childhood in Gampong Geudubang Aceh has been implemented with the existence of TPQ or Koranic places and not all Koran places teach Arabic vocabulary. However, in mastering Arabic vocabulary, it is only taught to elementary and junior high school-age children, while children aged 5-6 years are not applied in vocabulary mastery but are only introduced to hijaiyah letters (Iqra). With this, considering the teaching method at the kindergarten level to students through learning activities, the majority are still dominated by playing, storytelling, and singing activities. So the writer is interested in increasing mastery of Arabic vocabulary through the singing method in Gampong Gedubang Aceh, Langsa City. For this reason, researchers want to be interested in using the singing method in introducing Arabic vocabulary to early childhood, because the singing method can make the learning atmosphere cheerful and passionate so that children's development can be stimulated more optimally. In addition, singing can increase children's interest and can hone memory and singing can also develop the 
imagination to make it more creative. This is by the learning process in early childhood which is done by playing while learning (Nasir et al., 2016).

\section{CONCLUSION}

Judging from the results of the study, it can be concluded that the singing method carried out for children aged 5-6 years in Gampong Geudubang Aceh Langsa has been able to improve Arabic vocabulary mastery. Based on the data from the second cycle of assessment, there has been an increase in mastery of Arabic vocabulary in the number of children who are developing very well, which shows that there are $5(83 \%)$ children in the criteria for developing very well and as many as 1 (33\%) in the criteria developing as expected. . From these results, all of them experienced an increase which showed that children were able to understand Arabic vocabulary in the form of pronouncing Arabic vocabulary and children were able to sing Arabic vocabulary.

\section{REFERENCE}

Acep Hermawan. (2018). Metodologi Pembelajaran Bahasa Arab. Remaja Rodakarya.

Arikunto, S. (2015). Prosedur Penelitian Suatu Pendekatan Praktek. Rineka Cipta, Jakarta.

Arikunto, Suharsimi, \& Supardi, S. (2017). Penelitian Tindakan Kelas. Bumi Aksara.

Asef, U. F. (2018). Sukses Menjadi Seorang Guru PAUD. Remaja Rosdakarya.

Azzahra, H. (2017). MENINGKATKAN PENGENALAN KOSAKATA BAHASA ARAB MELALUI PEMANFAATAN MEDIA GAMBAR PADA ANAK KELOMPOK B DI RA AL-JANNAH JAKARTA. JPP PAUD UNTIRTA, VOL.4 No 2.

Depdiknas. (2009). Depdiknas. 2009. Permendiknas No . 58/2009 tentang standar Tingkat Pencapaian Perkembangan. Depdikbud.

Fauziddin, M., \& Tambusai. (2020). Mengenal Kosakata Bahasa Arab melalui Permainan Kartu Huruf Hijaiyah yang Dilengkapi Kosakata. Journal Of Education Research, Vol 1. No.

Hasan, M. (2009). Y. (n.d.). Pendidikan Anak Usia Dini. Diva Press.

Ibrahim, A. 'alim. (2011). Al muwajjah al fanni li almudarrisil lughah arabiah (17th ed.). Daarul Maarif.

Iskandar, D. dan N. (2015). Penelitian Tindakan Kelas dan Publikasinya Untuk Kenaikan Pangkat dan Golongan Guru E Pedoman Penulisan PTK bagi Mahasiswa. Cilacap:Ihya Media.

Isnaningsih, A. (2016). Pengaruh Metode Pembelajaran Bahasa Melalui Bernyanyi Dan Bercerita Terhadap Penguasaan Kosakata bahasa Indonesia Anak Tk Aba Seropandlingo Bantul Yogyakarta. Eprint@UNY.

Khotijah, I. (2018). Peningkatan Kemandirian Anak Melalui Pembelajaran Practical Life. 
Golden Age Pendidikan Guru Pendidikan Anak Usia Dini University Hamzawandi.

Mahriza, Meutia, Nina, N. (2019). IJLRES - International Journal on Language, Research and Education Studies ISSN : 2580-6777 ( $p$ ); 2580-6785 (e ) Visual and Cognitive Media: The Language Acquisition of Children With Dyslexia in Aceh. 3(1), 112-126. https://doi.org/10.30575/2017/IJLRES-2019010409

Mahriza, R., Ulya, M., \& Pratiwi, S. H. (2021). The phonic method for improving students' speaking ability. Atfāluna: Journal of Islamic Early Childhood Education, 4(1), 21-30. https://doi.org/10.32505/atfaluna.v4i1.2859

Mansur. (2005). Pendidikan Anak Usia Dini dalam Islam. Pustaka Belajar.

Munawaroh, S. (2017). Sa'diyatul Munawaroh (2017) penigkatan penguasaan kosa kata bahasa Arab pada anak usia dini di RA Masitoh Salatiga iga. Repository.Perpus.Iainsalatig.

Nasional, P., Katalog, R. I., \& Terbitan, D. (2016). Pembelajaran Bahasa Arab MI.

Nasir, M., Mukhlis, \& Rahmah, M. (2016). Eksistensi Bīah Lughawiyyah di Dayah Terpadu Al-Muslimun Lhoksukon Aceh Utara. Ihya Al-Arabiyah, 2(1), 117-136.

Nur Hamim dan Husniyatus Salamah. (2009). Penelitian Tindakan Kelas. Surabaya: PT. Revka Petra Media.

Purwanto, N. (2006). Prinsip-prinsip danTeknik Evaluasi Pengajaran. Rosda Karya.

Risaldy, S. (2014). Bermain, Bercerita dan Menyanyi. PT. Luxima Metro Media.

Shiddiq, U. (2008). T; lim lughah arabiah lighairi natiqi nabiha. Daar Alamiah.

Sumarni. (2015). Peningkatan Hasil Belajar Siswa Menggunakan Metode Kerja Kelompok Dalam Pembelajaran IPA Di Sekolah Dasar. TKIP UNTAN Pontianak, Vol.4, No.

Susanto, A. (2012). Perkembangan Anak Usia Dini. Kencana. 